both the meteorological and radio aspects of the whole investigation.

As the various items of all this work reached appropriate stages, reports were prepared and issued as confidential or secret documents under the restric. tions of war-time conditions. But the value of the research from the point of view of the scientific world has now been considerably enhanced by the fact that many of the results obtained have been placed on permanent record in the form of published papers. In the first place, the propagation of ultrashort waves formed the subject of one of the sessions of the Radiolocation Convention of the Institution of Electrical Engineers held in March 1946. The resulting papers and lecturettes were published in a special number of the Institution's Journal (93, Part IIIA, No. 1, 1946). This Convention was followed in April of the same year by a Joint Conference held by the Physical and the Royal Meteorological Societies, at which the various aspects of the influence of atmospheric conditions on the propagation of radio waves was discussed in considerable detail ; and in Nature of June 29, 1946 (157, 860), Prof. P. A. Sheppard gave a detailed account of this Conference and of the various papers presented at it.

The report of the latter Conference has now been published by the Physical Society as a special volume entitled "Meteorological Factors in Radio-Wave Propagation" (price to non-members 24s. including postage). This volume contains the full text of the ten papers read at the meeting, together with eleven other papers describing work on various closely related subjects. Dr. J. A. Saxton gives an account of the experimental determination of the dielectric properties of steam for frequencies between 3,000 and 20,000 Mc./s. (wave-lengths 1.5-10 cm.). The results of such measurements were used to estimate the amount of attenuation to be expected, due to atmospheric water vapour, in the transmission of these waves through the lower atmosphere. The estimated values of such absorption are found to be reasonably consistent with those obtained from theoretical considerations. In four subsequent papers the same author, in one case jointly with J. A. Lane, has studied experimentally and theoretically the anomalous dispersion of water in the centi. metre wave-range. The results of this work have provided a detailed knowledge of the refractive index and absorption coefficient of liquid water over a wave-length range from $10 \mathrm{~cm}$. down to a few millimetres, and of the variations of these quantities over the temperature range $0^{\circ}-40^{\circ} \mathrm{C}$.

In a paper entitled "Observations of Unorthodox Radar Vision in the Vicinity of New Zealand and Norfolk Island", Dr. F. E. S. Alexander presents and analyses many observations of anomalous wave propagation obtained by the operators of radar stations on wave-lengths of 10.5 and $150 \mathrm{~cm}$. Another paper, by J. A. Ramsay, describes the results of further observations made at radar stations using wave-lengths of $1 \cdot 25,3$ and $10 \mathrm{~cm}$. The conditions of propagation were studied at a nominally fixed range, by raising the reflecting target to known heights above the sea by means of a balloon. The results confirmed the prediction, made on theoretical grounds, that anomalous propagation would be experienced on a wave-length of $1.25 \mathrm{~cm}$. to a much greater extent than on $10 \mathrm{~cm}$.

The remaining papers deal with various aspects of the vertical gradient of refractive index in the atmosphere and its effect on the propagation of the very short radio waves under consideration. Dr. G. G. Macfarlane describes a method of deducing the refractive index gradient in a stratified atmosphere from radio observations: while G. A. Bull has provided a note on errors in the measurement of the refractive index consequent upon errors in the meteorological measurements from which the index is deduced. Using information provided by published weather charts, supplemented by some special measurements made in Great Britain, Dr. A. C. Stickland has studied the average condition of the atmosphere as a refracting medium for the propagation of radio waves. From this empirical study, it is shown that the average refractive index of the lower atmosphere varies logarithmically with height, the actual radius of curvature of the path of the waves increasing linearly with height above the earth's surface.

In a field of investigation such as this, where the meteorologist and radio scientist meet on common ground, it is clearly desirable that there shall be some agreement on the definition of what may be termed a 'standard atmosphere', to which both theoretical and experimental investigations may be referred. It is therefore very appropriate that the publication now under review should include a paper by A. C. Best entitled "A Standard Radio Atmosphere for Microwave Propagation". The author discusses three possible definitions of standard atmosphere, one of which is already in use for aeronautical purposes; but he suggests that the final choice of definition for the standard radio atmosphere must be made by the radio investigator rather than by the meteorologist.

All the work described above represents the conclusion of a very satisfactory and highly successful series of investigations initiated and conducted under war-time conditions. It demonstrates the ability of a large body of scientific workers and Service personnel to plan and conduct in an efficient manner a very complicated research programme in the laboratory and in the field. In spite of the varying interests of the many individuals concerned, they worked together as an enthusiastic team and were inspired in the main by two British Government committees. One of these was under the chairmanship of Sir Edward Appleton, who at the end of his introductory paper to the joint Conference mentioned above acknowledges with pleasure the collaboration he received from its members. $\mathrm{He}$ also states that his committee, or, to give it the full title, the Ultra-Short Wave Panel of the Ministry of Supply, had the good fortune to work in close collaboration with the U.K. Joint Radio Meteorological Committee, under the chairmanship of Sir Nelson Johnson, and also with the U.S. Wave Propagation Committee under the chairmanship of Dr. C. R. Burrows.

R. L. SMITH-ROSE

\section{RELEASE OF INFORMATION ON ATOMIC ENERGY}

$T$

WO lists of British reports on atomic energy, which had been 'declassified' and made available for purchase through H.M. Stationery Office, P.O. Box 569, Cornwall House, London, S.E.1, were announced last year (Nature, March 22, p. 411, September 27, p. 445). The following further twentythree reports have now been released and should, wherever possible, be ordered by B.D.D.A. number ; if this is given, no other identification is needed. 
It is hoped that, in the future, reports will be supplied to H.M. Stationery Office as and when they are declassified, and no special announcements will be made; information as to the latest reports available would then be obtained from the regular announcements from H.M. Stationery Office.

\begin{tabular}{|c|c|c|c|c|}
\hline $\begin{array}{l}\text { B.D.D.A. } \\
\text { No. }\end{array}$ & $\begin{array}{l}\text { Report } \\
\text { No. }\end{array}$ & Title and Author(s) & Date & Price \\
\hline 99 & Br. 10 & $\begin{array}{l}\text { Organic derivatives of U. } \\
\text { N. Haworth }\end{array}$ & & 28. $8 d$. \\
\hline 100 & Br. 18 & 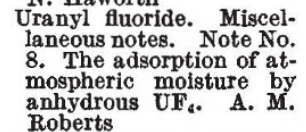 & $\begin{array}{l}\text { Feb. } 16 \\
1942\end{array}$ & 28. $0 d$. \\
\hline 101 & Br. 174 & $\begin{array}{l}\text { Investigation of the Pres- } \\
\text { sure-density relationship } \\
\text { for the hexafluoride of } 0 \\
\text { at } 49 \cdot 2^{\circ} \mathrm{C} \text {. C. B. Amph- } \\
\text { lett and } \mathrm{L} \text {. F. Thomas }\end{array}$ & $\begin{array}{l}\text { Feb. } 28, \\
1042\end{array}$ & 28. Od. \\
\hline 102 & Br. 27 & $\begin{array}{l}\text { Uranyl fluoride. Miscel- } \\
\text { laneous notes. Note No. } \\
\text { 18. The true and packing } \\
\text { densities of anhydrous } \\
\text { UF a. A. M. Roberts, } \\
\text { B. G. Harvey }\end{array}$ & $\begin{array}{l}\text { Mar. 30, } \\
1942\end{array}$ & 18. $4 d$. \\
\hline 103 & Br. 36 & $\begin{array}{l}\text { The reduction of UF, by } \\
\text { hydrogen. J. Ferguson }\end{array}$ & $\underset{1942}{\operatorname{May} 14}$ & 48. $0 d$. \\
\hline 104 & Br. 182 & $\begin{array}{l}\text { Pressure density relation- } \\
\text { ship for UF, at } 50^{\circ} \text { C.; } \\
\text { revised flgure for } \\
\left(\frac{\partial e}{\partial p}\right)-50^{\circ} \text {. C. B. Amph- }\end{array}$ & $\begin{array}{c}1942 \\
1942\end{array}$ & 28. $0 d$. \\
\hline 105 & Br. 186 & $\begin{array}{l}\text { lett } \\
\text { The vapour pressure of } \\
\text { UF } \text { from }_{6} \text { fro to } 50^{\circ} \mathrm{C} \text {. } \\
\text { C. B. Amphlett }\end{array}$ & $\begin{array}{l}\text { June } 30 \\
1942\end{array}$ & 28. $0 d$. \\
\hline 106 & Br. 187 & $\begin{array}{l}\text { Determination of the va- } \\
\text { pour density of UF } \mathrm{UF}_{\mathrm{g}} \text { at } \\
\text { room temperature. C. B. } \\
\text { Amphlett and L. F. } \\
\text { Thomas }\end{array}$ & $\underset{1942}{J u n e} 30$ & 18. $4 d$. \\
\hline 107 & Br. 222 & $\begin{array}{l}\text { The analysis of gaseous } \\
\text { fluorine, Part } \mathbf{I} \text {. The de- } \\
\text { termination of total and } \\
\text { free fluorine. } \\
\text { Williams }\end{array}$ & $\begin{array}{l}\text { Sept. 14, } \\
1942\end{array}$ & 78. $4 d$. \\
\hline 108 & Br. 188 & $\begin{array}{l}\text { Determination of the ultra- } \\
\text { violet absorption of } \\
\text { UF. vapour. A. E. Mar- } \\
\text { tin and C. B. Amphlett }\end{array}$ & $\begin{array}{l}\text { Nov. } 30 \\
1942\end{array}$ & 28. $0 d$. \\
\hline 109 & Br. 166 & $\begin{array}{l}\text { Gland experiment. H. S. } \\
\text { Arms }\end{array}$ & $\underset{1943}{\text { Jan. 20, }}$ & 88. $8 d$. \\
\hline 110 & Br. 167 & $\begin{array}{l}\text { Fxperiments on the pres- } \\
\text { sure dependence of heat } \\
\text { conductivity concentra- } \\
\text { tion meters. A. F. Brown }\end{array}$ & Mar. 1, & 68. $8 d$. \\
\hline 111 & Br. 242 & $\begin{array}{l}\text { Absolute calibration of a } \\
\text { neutron source. } \\
\text { Frisch }\end{array}$ & $\begin{array}{l}\text { June } \\
1043\end{array}$ & 58. $4 d$. \\
\hline 112 & Br. 280A & $\begin{array}{l}\text { Remarks on some physical } \\
\text { properties of uranium } \\
\text { metal. F. E. Simon }\end{array}$ & $\underset{1943}{\text { Aug. } 16}$ & 88. $0 d$. \\
\hline 113 & Br. 281 & $\begin{array}{l}\text { The viscosity of gaseous } \\
\text { fluorine. Critical litera. } \\
\text { ture survey. Rudge and } \\
\text { Southam }\end{array}$ & $\underset{1943}{\text { Aug. } 23,}$ & 68. $0 d$. \\
\hline 114 & Br. 315 & $\begin{array}{l}\text { Notes on Br. } 44 \text { "On the } \\
\text { Correction for Self-Ab- } \\
\text { sorption in } \beta \text {-Ray Meas- } \\
\text { urements", Broda, Guer- } \\
\text { on and Kowarski, 1942. } \\
\text { N. Feather }\end{array}$ & Aug. 16 & 68. $0 d$. \\
\hline 115 & Br. 425 & $\begin{array}{l}\text { Determination of } U^{2 a s} \text { con- } \\
\text { tent of enriched uranium } \\
\text { samples. E. Bretscher } \\
\text { and E. B. Martin }\end{array}$ & $\begin{array}{l}\text { Nov. } 3 \text {, } \\
1943\end{array}$ & 28. $0 d$. \\
\hline 116 & Br. 397A & $\begin{array}{l}\text { Memorandum on American } \\
\text { tests on fluorocarbon lube } \\
\text { oils. J. R. Park }\end{array}$ & $\underset{1944}{\operatorname{Mar}} 16$ & 18. $4 d$. \\
\hline 117 & Br. 516 & $\begin{array}{l}\text { A hard valve pulse analyser. } \\
\text { M. I. Poole }\end{array}$ & $\underset{1944}{\operatorname{May} 7}$ & 128. Od. \\
\hline 118 & BI. 37 & $\begin{array}{l}\text { Stability of solutions of } \\
\text { UCl in alcohol, acetone, } \\
\text { and water. C. B. Amph- } \\
\text { lett }\end{array}$ & $\begin{array}{l}\text { May } 31 \\
1944\end{array}$ & 28. $0 d$. \\
\hline 119 & Br. 673A & $\begin{array}{l}\text { The analysis of nitrogen - } \\
\text { argon mixtures. P. A. I. } \\
\text { Tahourdin }\end{array}$ & $\underset{1945}{\operatorname{Dec} .7}$ & 4s. $8 d$. \\
\hline 120 & Br. 718A & $\begin{array}{l}\text { The tensile properties of } \\
\text { uranifum at elevated tem- } \\
\text { peratures in the } \alpha \text {-range. } \\
\text { National Physical Lab- } \\
\text { oratory }\end{array}$ & $\underset{1946}{\operatorname{Mar}}{ }^{4}$ & 18. $4 d$. \\
\hline 121 & Br. 775 & $\begin{array}{l}\text { Preliminary creep tests on } \\
99 \cdot 8 \% \text { aluminium at } \\
300^{\circ}, 350^{\circ} \text { and } 400^{\circ} \mathrm{C} \text {. } \\
\text { British Non-Ferrous Met- } \\
\text { als Research Association }\end{array}$ & July 1947 & 68. $8 d$. \\
\hline
\end{tabular}

\section{FORESTRY IN TRINIDAD AND TOBAGO}

THE present forest policy for the Colony of Trinidad and Tobago has had several predecessors. The Annual Forest Administration Report for the Year 1946, written by Mr. John Carter, acting conservator of forests, starts with a statement on the present forest policy formulated in 1942 and now formally accepted by the Government and the Secretary of State for the Colonies. Briefly sum. marized, it is as follows : (a) Permanent reservation by the Crown of suitably situated areas of forest of a total acreage sufficient to supply the objects aimed at, both direct and indirect. (b) Management of reserved forests on the basis of a sustained yield. (c) The fullest utilization of the forest products, based on the correct forest management and the most economic utilization of imported lumber. (d) Organised research in all branches of forestry. (e) A fully trained staff, both gazetted and subordinate, and the education of all classes of the com. munity to understand the benefits of forestry. (f) The encouragement of, and assistance to, private forestry. (g) Co-operation between forestry and other land interests with the object of bringing into force a sound land utilization policy.

These are good clauses in a correct forest policy. They have been enunciated on more or less similar lines many times in the past in the British Empire. It would appear from the action being taken both in the Empire and outside it in other parts of the world that Governments generally have become conscious of the serious dangers which are threatening their populations through wasteful utilization of the forest resources, involving possible wood famines in certain regions of the globe, and seriously increasing erosion and degradation of soils and interference with water supplies and rainfall.

The present report describes the steps being taken in carrying out the resolutions on the above heads of policy. The report then continues with details on the actual work carried out during the year. Among other points the question of game preservation and the difficulty of control in the close season is men. tioned : and also that negotiations were continued with the Trinidad Field Naturalists Club with a view to the formation of a zoological society which would undertake to establish and maintain a zoological 'garden'. It is interesting to note that a site of about 6 acres in the Royal Botanic Gardens has been made available for the proposed zoo, and the Government has agreed to hand over to a zoological society when it is formed the funds standing to the credit of the Wild Birds Fund, and an annual grant equal to the amount collected for hunting licences.

\section{FORTHCOMING EVENTS}

(Meetings marked with an asterisk * are open to the public)

Monday, January 26

Royat SOcIRTy of ARTs (at John Adam Street, Adelphi, Iondon, W.C.2), at 4.30 p.m.-Dr. C. H. Andrewes, F.R.S.: "The Common Cold" (Cantor Lecture).

UNIVRRSITY COLLEG L LONDON (in the Physiology Theatre, Gower Street, London, W.C.1), at 4.45 p.m.-Dr. Ernest Baldwin: "The Comparative Biochemistry of Respiration and Metabolism". (Further Lectures on February 2, 9, 16, 23 and March 1.)*

MaNCHESTHR Literary aND PHIlosophical SOCIETY (in the Reynolds Hall, College of Technology, Manchester), at 5.30 p.m.-Sir George Thomson, F.R.S.: "Determinism in the Physical World" (Joule Memorial Lecture).* 